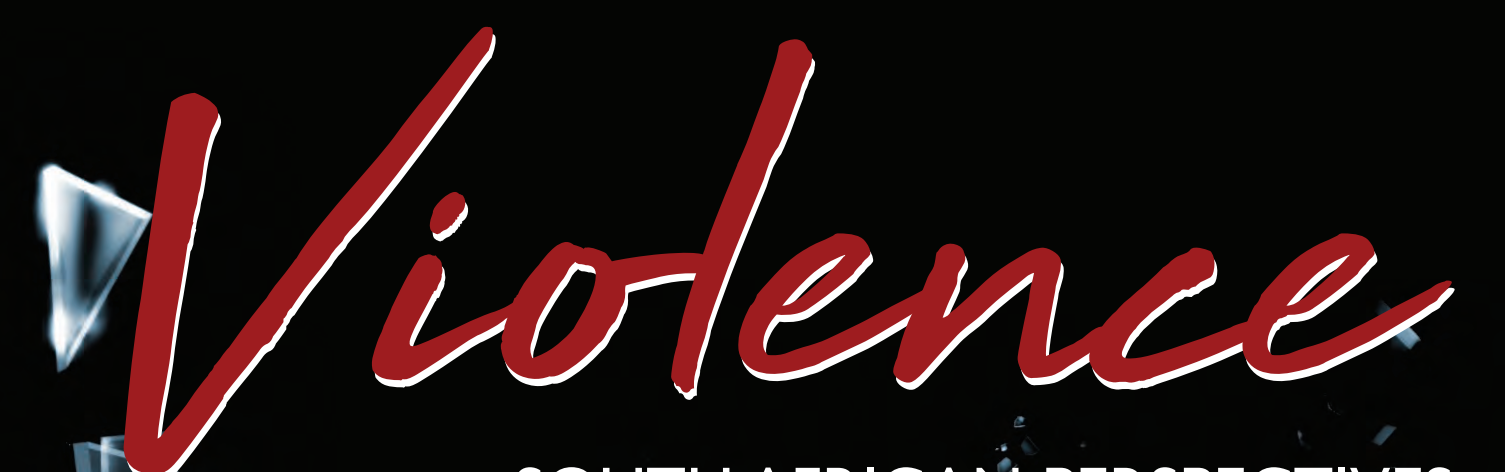

SOUTH,AFRICAN PERSPECTIVES

$\rightarrow$

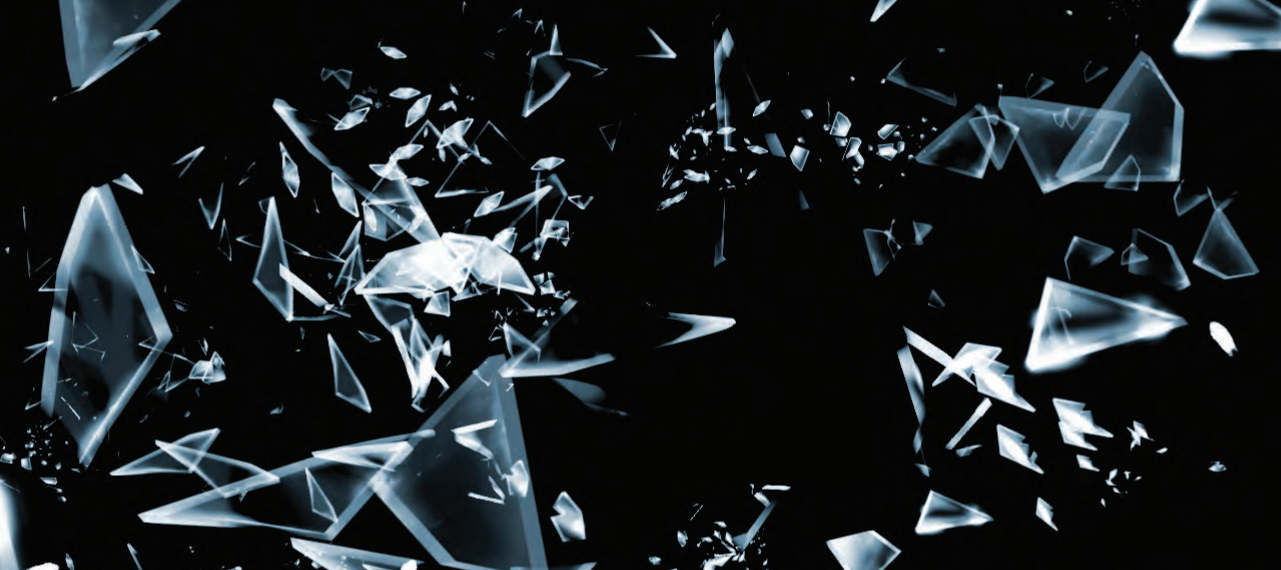

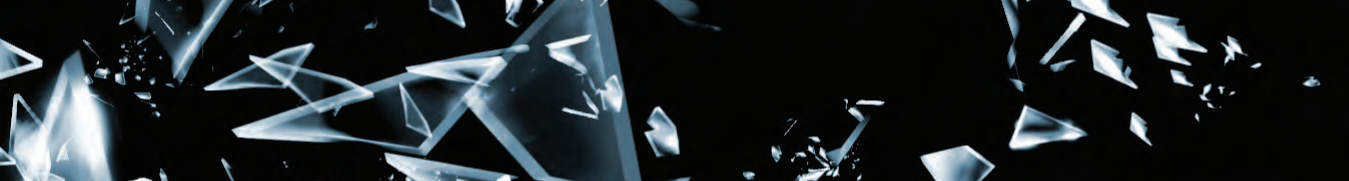

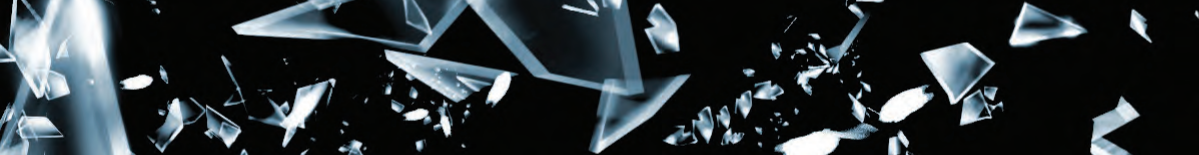

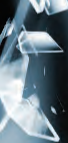

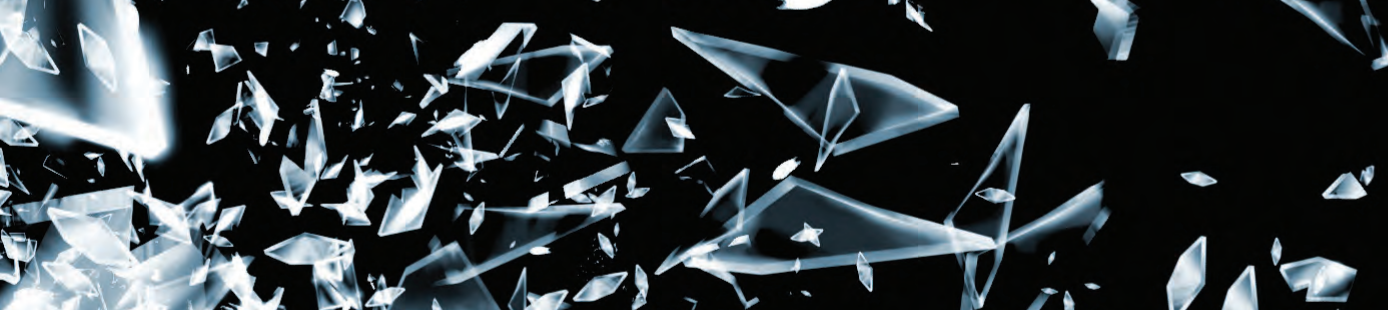

,

a 4 < 6

QX

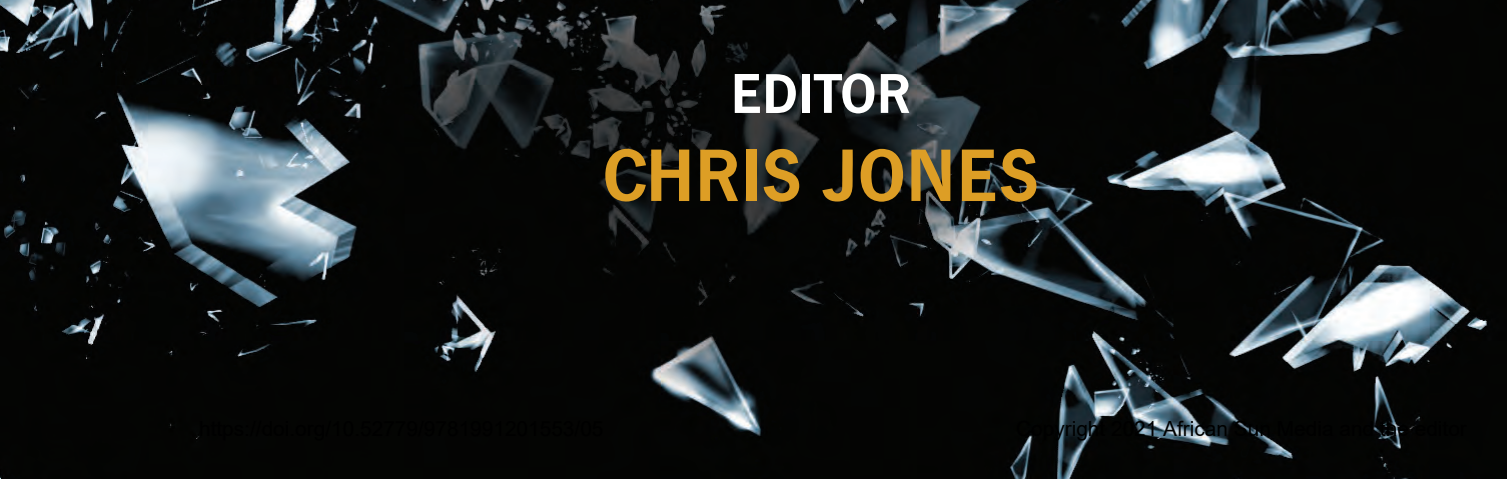




\section{VIOLENCE AGAINST PERSONS WITH DISABILITIES}

Pieter van Niekerk

\section{Keywords}

Convention on the Rights of Persons with Disabilities (CRPD); disability; disability-related violence; forms of abuse and neglect; Sobsey and Calder's Multifactorial Model; stereotypes; victimisation; violence

\section{INTRODUCTION}

This chapter gives a peek into the agonising reality and predominantly silent cries of persons with disabilities who are confronted with acts of violence during their lifetime. Violence and disability as phenomena are discussed. The fact is shared that stereotyping and stigmatisation of persons with disabilities are pervasive in some communities. The Multifactorial Model of Sobsey and Calder (1999) is given. This model gives an explanation of the forces of interpersonal power that operate in situations of violence affecting persons with disabilities. The various forms of abuse and neglect are contextualised by persons with disabilities telling their own stories.

I am Refilwe, I am severely disabled. A man at my day care raped me every day while my mother was at work. My mother found out and took me to the hospital. The doctor said I had been raped a lot but did not offer us any counselling. My mother pressed charges. The police dropped the charges because I cannot walk or talk. They said I can't testify because I cannot tell anyone what happened. The day care says that the police did not ask any of the employees to give DNA. I have no voice to voice my pain, and no one will help my mother. I am Refilwe, I was raped repeatedly and authorities do not care.

(Vorster \& Magnes 2018)

\section{VIOLENT SOUTH AFRICA}

The political history of South Africa is strongly associated with violence - the apartheid system was established and continued by both structural and interpersonal violence (Neille \& Penn 2015:5). Cycles of violence still continue. While interpersonal violence is a prominent cause of death, "Cape Town is known as the eighth most violent city in the world" according to international homicide statistics (Businesstech 2020). The risk of being a victim of violence correlates with a combination of the factors' context, socio-economic status, age, and gender (Neille \& Penn 2015:5). 
Vulnerability rises proportionally to the difference in power between perpetrator and victim, inadequacy of support structures, disability, as well as economic or emotional dependence on the offender, having no "voice" or opportunity to make a report on violence, or repeated exposure to violence over the life course (Plummer \& Findley in Neille \& Penn 2015:5).

\section{VIOLENCE}

The phenomena of violence and disability are loaded with meaning and interpretations. A workable definition of violence according to the World Health Organization (WHO) (Krug, Dahlberg, Zwi \& Lozano 2002:5) is

the intentional use of physical force or power, threatened or actual, against oneself, another person, or against a group or community, that either results in or has a high likelihood of resulting in injury, death, psychological harm, maldevelopment, or deprivation.

According to an ancient source, the Bible (Matt. 5:21-22), murder and verbal insults are comparable. Both are crimes and equally punishable before the law. It follows that denigrating or abusing another is equal to 'killing' human dignity.

A valuable framework for unpacking the complexities of violence happening in the everyday lives of individuals and families was developed by the WHO (Krug et al. 2002:7) (Figure 5.1). There are three categories of violence: self-directed, interpersonal, and collective. These categories are further divided to reflect specific types of violence. Acts of violence are classified by its nature: physical, sexual, psychological, or involving deprivation or neglect. The horizontal grouping indicates who are affected. The vertical grouping describes how these persons are affected. People with disabilities are represented in each of the categories of affected people.

\section{DISABILITY}

Disability is an umbrella term. According to Article 1 of the Convention on the Rights of Persons with Disabilities (CRPD) (UN 2007), "[p]ersons with disabilities include those who have long-term physical, mental, intellectual or sensory impairments which in interaction with various barriers may hinder their full and effective participation in society on an equal basis with others". Impairments are defined as body function and/ or structure problems, for example a significant deviation or loss (WHO 2001:10).

The conceptualisation of disability has progressed from the outdated charity model to the medical model, and a subsequent shift to the social and human rights-based model (UNICEF 2014:12) (Text box 5.1). According to the medical model, disability 


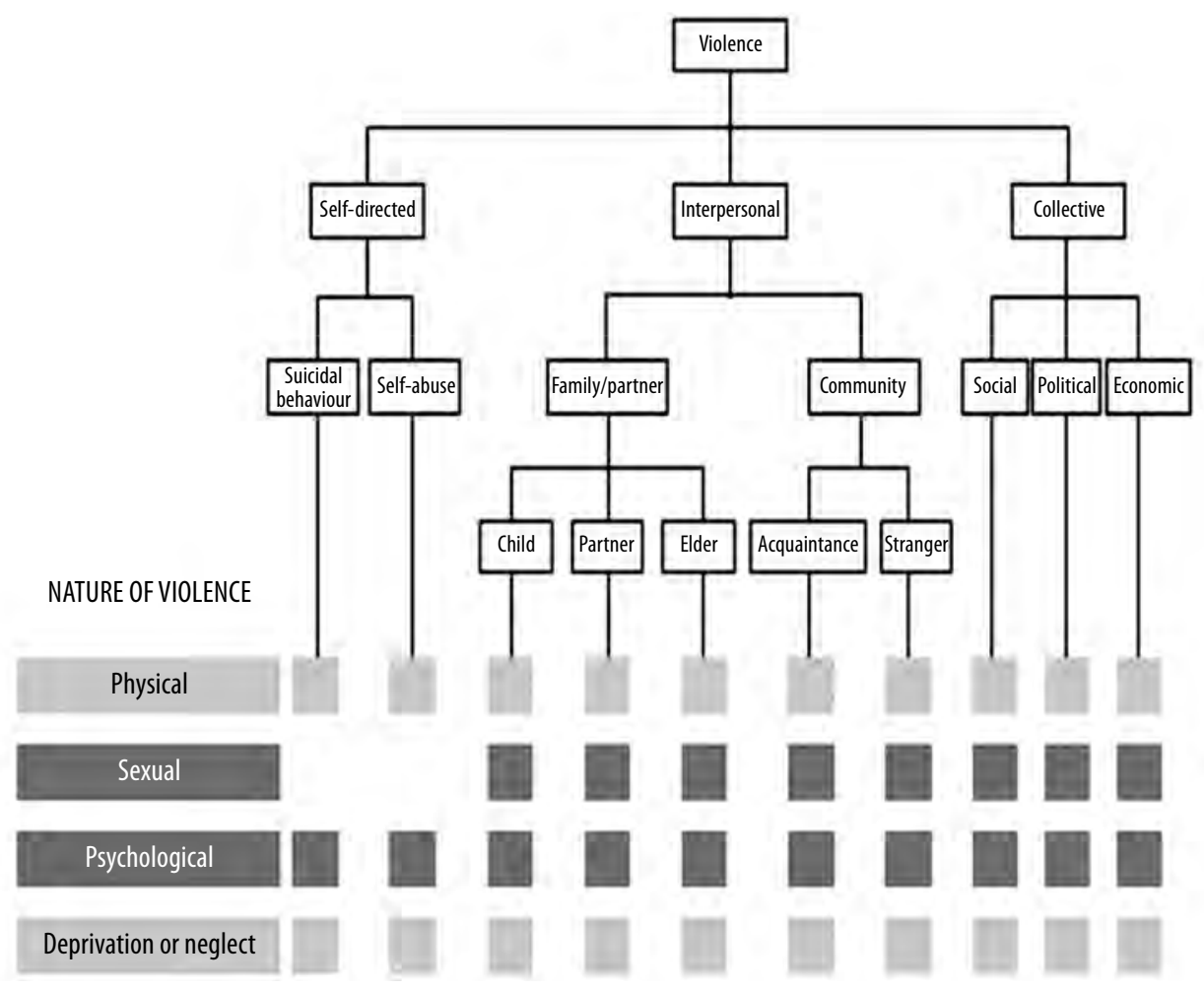

FIGURE 5.1 Typology of violence according to the WHO

is regarded as a medically related condition which can be treated and healed. According to the social model, the extent to which individuals' impairments are 'disabling' them, exposes the magnitude of physical, informational and/or communicational barriers in the environment and negative attitudes found in their community. When impairments are accepted as an expression of human variation, optimal functioning of persons with disabilities is facilitated and they can enjoy meaningful lives through participation in all life situations similarly to their counterparts without impairments.

The inequalities that define disability are linked with poverty, barriers to employment, education and health care, inaccessible spaces, stigma and negative societal attitudes, denial of their sexuality, and vulnerability to violence and abuse. Disability is no longer solely a bio-medical or a social issue but a human rights issue. Interpersonal violence is another human rights issue and is a common feature in the lives of South Africans.

(Van der Heijden, Abrahams \& Harries 2016:2) 
Charity Model of Disability - Well-being is in the hands of the gods or destiny.

- Disability is a punishment or a tragedy.

- Individual seen as needy, pitiful, even as blameworthy.

- Salvation through mercy, love and care.

Medical Model of Disability - Well-being is in the hands of doctors.

- Disability is a condition of the individual that can be treated.

- Individual seen as being in need of a cure or management of illness.

- It is the health professional's responsibility and potential to alleviate pain.

Social Model of Disability - Well-being is in the hands of society.

- Disability is a societal problem.

- Individual seen as being a victim of social prejudice.

- Society has the responsibility to eliminate barriers.

TEXT BOX 5.1 Models explaining disability (UNICEF 2014:12)

According to the 2011 Census (Statistics South Africa 2014:v, 152), 7.5\% of South Africans over the age of five years were persons with disabilities (Table 5.1). However, the institutionalised population was excluded, as well as persons with psycho-social and particular neurological disabilities. Variation in terms of incidence occurred. For example, the highest prevalence was found in the Free State and the Northern Cape provinces respectively, and the lowest in Gauteng (Statistics South Africa 2014:v, 57).

TABLE 5.1 Prevalence of disability in South Africa according to province

\begin{tabular}{|l|r|r|r|r|r|r|}
\hline \multirow{2}{*}{ Province } & \multicolumn{2}{|c|}{ With disabilities } & \multicolumn{2}{|c|}{ Without disabilities } & \multicolumn{2}{|c|}{ Total } \\
\cline { 2 - 6 } & $\mathrm{N}$ & $\%$ & $\mathrm{~N}$ & $\%$ & $\mathrm{~N}$ & $\%$ \\
\hline Western Cape & 222333 & 5.4 & 3914513 & 94.6 & 4136846 & 100.0 \\
\hline Eastern Cape & 472106 & 9.6 & 4448179 & 90.4 & 4920285 & 100.0 \\
\hline Northern Cape & 92731 & 11.0 & 747310 & 89.0 & 840041 & 100.0 \\
\hline Free State & 234738 & 11.1 & 1888869 & 89.0 & 2123607 & 100.0 \\
\hline KwaZulu-Natal & 620481 & 8.4 & 6728673 & 91.6 & 7349154 & 100.0 \\
\hline North West & 254333 & 10.0 & 2285298 & 90.0 & 2539631 & 100.0 \\
\hline Gauteng & 485331 & 5.3 & 8627419 & 94.7 & 9112750 & 100.0 \\
\hline Mpumalanga & 205280 & 7.0 & 2727519 & 93.0 & 2932799 & 100.0 \\
\hline Limpopo & 282797 & 6.9 & 3846966 & 93.2 & 4129763 & 100.0 \\
\hline South Africa & 2870130 & 7.5 & 35214746 & 92.5 & 38084876 & 100.0 \\
\hline
\end{tabular}




\section{DISABILITY-RELATED VIOLENCE}

A young woman in a wheelchair experienced abuse at the hospital where she went to have an abortion. Health care staff shunned her for being pregnant and also interrogated her ability to have sex or become pregnant: And even when I went to have my abortion, I went to this one hospital, and this nurse says to me: 'how did you get pregnant? I didn't know you could 'do it' [have sex] in wheelchairs?' She reported that one of the nurses told her that to have a disability is already a burden, and that being pregnant would double the burden, so she must have an abortion.

(Van der Heijden et al. 2016:10)

Although people with disabilities experience the same kinds of violence than persons without disabilities (Figure 5.1), they are also confronted with forms of abuse that are specific to having an impairment (Powers \& Oschwald 2004:4). According to adults with disabilities, there are seven major categories of abusive behaviour specific to having an impairment (ibid:4-5):

1. Physical abuse

2. Sexual abuse

3. Verbal or emotional abuse

4. Neglect or withholding support

5. Financial abuse

6. Manipulation of medications

7. Destroying or disabling equipment

Three identified categories of abuse are disability-related: denial of personal assistance and support, tampering with medication, and deactivation of disability equipment. The additional element to simply exercising power over the victim is that the perpetrator is also exploiting the victim's vulnerability linked to an impairment. Disability-related abuse is often associated with the caregiving relationship on which many persons with disabilities depend upon, for example, when they are institutionalised (Powers \& Oschwald 2004:5).

A distinction can be made between active and passive violence (Iglesias, Gil, Joneken, Mickler \& Knudsen 1998:n.p.). Active violence refers to the commission of an act of aggression, such as with physical, sexual, emotional, and economic maltreatment. Passive violence refers to an omission of an act of caregiving. Physical and emotional neglect, and actions involving the risk of physical or psychological harm to the victim are considered to be passive forms of violence.

\section{Physical abuse}

This form of violence can be described as any direct or indirect action that can harm the person's life, health or well-being or can cause pain or unnecessary suffering (Naidu, Haffejee, Vetten \& Hargreaves 2005:n.p.). Examples are the unjustified administration of tranquilisers to silence her or him, restricting mobility by removing an assistive device, and aggressive acts that result in physical injury and/or pain. 


\section{Emotional abuse}

A paraplegic woman living in a shack behind her sister's house reported how when her family would leave for work, it was difficult for her to enter their house to use the toilet:'They sometimes go out and lock up the house, and then I have no place to go [to the toilet].

(Van der Heijden et al. 2016:9)

Emotional abuse can be described as an insult to the emotional well-being of the individual (Naidu et al. 2005:n.p.). Included here are actions of control that restrict access to family and/or friends or socially isolate the person, verbal abuse, ter rorisation, and emotional blackmail. Specifically, with regards to persons with disabilities, threats may be about leaving without giving required assistance for feeding or toileting, or to have him or her institutionalised. Taunting or creating confusion through the deliberate use of complex language for communicating with a person with a cognitive impairment also falls under this form of maltreatment.

\section{Sexual abuse}

Sexual violence can be described as sexually aggressive behaviour towards a person that can result in physical and/or emotional harm (Naidu et al. 2005:n.p.). General examples are rape and sexual assault. Sexual exploitation and sexual grooming as actions of sexual violence towards persons with intellectual disabilities are criminal offences according to the Sexual Offences Act. Sexual exploitation is defined as the "actual or attempted abuse of a position of vulnerability, power, or trust, for sexual purposes, including, but not limited to, profiting monetarily, socially or politically from the sexual exploitation of another" (WHO n.d.). In this context, sexual grooming is the gradual process of preparing a person with an intellectual disability to participate in sexual activities (CALS n.d.).

\section{Economic abuse}

This form of abuse can be described as the commission or omission of actions that result in "the loss of control over or rights to the means of survival (including property, money and/or employment)" (Naidu et al. 2005:n.p.). Peculiar to persons with disabilities are the exploitation of disability grants by family members and/or carers. Also, unauthorised withdrawal from accounts of persons who are visually impaired or immobile by others who do financial transactions on their behalf.

\section{Physical neglect}

Physical neglect can be described as depriving a person with a disability from basic care that she or he requires to be healthy and safe (Naidu et al. 2005:n.p.). This includes negligence with regards to feeding, basic hygiene and toileting, and insufficient supervision. The Life Esidimeni incident (Text box 5.2) is a poignant example. 
In 2016, at least 144 patients with intellectual disability died in the Life Esidimeni massacre, as a result of neglect. Initially the patients were well cared for by the privately owned Life Group, but then they were transferred to the care of mainly unlicensed health care providers contracted by the Gauteng Department of Health. The cancellation of the Life Group contract by the department was motivated by cutting costs, and the patients died from hunger, thirst and cold (Van Niekerk 2019:191; Capri et al. 2018).

TEXT BOX 5.2 The Life Esidimeni saga

\title{
Emotional neglect
}

A woman with muscular dystrophy reported her vulnerability as follows: I'm scared at home, I am all alone, with no one to help me if I fall ... I have nothing to do and no one to talk to'.

(Van der Heijden et al. 2016:9)

This form of passive violence can be described as unresponsiveness and disregard of the individual. It is the denial of attention, respect and consideration towards persons with disabilities (Naidu et al. 2005:n.p.).

\section{STEREOTYPES, STIGMA AND MYTHS}

Many African languages use expressions denoting animals or things when referring to people with disabilities and thereby insinuating they are lesser people (Kabue 2013:2). In a study conducted between 2013 and 2015 amongst 30 women from Cape Town with physical disabilities (Van der Heijden et al. 2016:4), psychological abuse took the form of stigmatisation through name calling (ibid:10):

\begin{abstract}
Since they were young, women had been called dehumanizing names such as inkawu (monkey) or isidalwa (creature). Others were labeled isishwawa (a punishment or burden) or isidenge (not right in the head) by family members, peers, and strangers. Some reported their male partners would call them 'dumb', 'useless,', 'a fool', or 'someone who has no brain' - insinuating they were mentally impaired.
\end{abstract}

There are five main social stereotypes linked to cognitive distortions contributing to violence against persons with disabilities (Sobsey in Naidu et al. 2005:n.p.):

\section{Dehumanisation}

People with disabilities are seen to be inferior and 'less human' than persons without disabilities. In this way, abusive behaviour towards persons with disabilities is appraised as 'less serious'.

\section{Damaged goods}

People with disabilities are viewed to be 'defective' and subsequently, with lesser value than persons without disabilities. Such reasoning justifies medical experiments that use persons with disabilities as guinea pigs. 


\section{Insensitivity to pain}

Persons with developmental disabilities in particular are sometimes considered to not experience physical and/or emotional pain. In this way forced abortions or sterilisations are allowed.

\section{Disabled menace}

Persons with disabilities are regarded as posing a threat to general society. Violence against this group is therefore justified as self-defence.

\section{Helplessness}

When women with disabilities are viewed as vulnerable, helpless, and dependent on others, they turn into 'easy prey' for sexual abuse.

The social discourse on the sexuality of persons with developmental disabilities often includes opposing stereotypes. On the one hand, these individuals are 'desexualised' and consequently made 'less human' by being viewed as asexual (Higgins \& Swain 2010:170). They are seen to not develop sexually, and that they therefore do not have sexual feelings or needs. On the other hand, there is the stereotype that males with intellectual impairment are oversexed perverts (Clements, Clare \& Ezelle 1995:432; Anderson \& Kitchin 2000:1166). The latter stereotype particularly relates to the stigma of the 'disabled menace' who puts society at jeopardy.

Superstition regarding albinism is associated with stigmatisation and rejection, and consequently restricted social integration (Franklin, Lund, Bradbury-Jones \& Taylor 2018:3). Visibly different, they are sometimes seen as white persons in a black community. According to fallacy, the health issues of persons with albinism are confirmation that they are cursed; they are "omens of disaster" (ibid). People with albinism are killed for their body parts that are sold for witchcraft and used for rituals of good fortune (ibid:2). Poverty is a strong driving force to maintain the market for body parts (ibid:4).

\section{VICTIMISATION}

Bronfenbrenner (1994) formulated the bioecological model of human development. An individual's development unfolds through progressively complex relatively stable and continuous interactions in different systems (Figure 5.2). The family is proximal to the individual and forms the microsystem. This system is embedded in a mesosystem of connections between microsystems to which she or he belongs. The exosystem consists of systems, such as the neighbourhood and community, and holds distal processes that may have nothing to do with the person, but which can still have an indirect impact on her or him. The macrosystem is described as a "societal blueprint" (Bronfenbrenner 1994:40) of the family's expression of culture. And last, the chronosystem refers to "historical time" (ibid:40). 


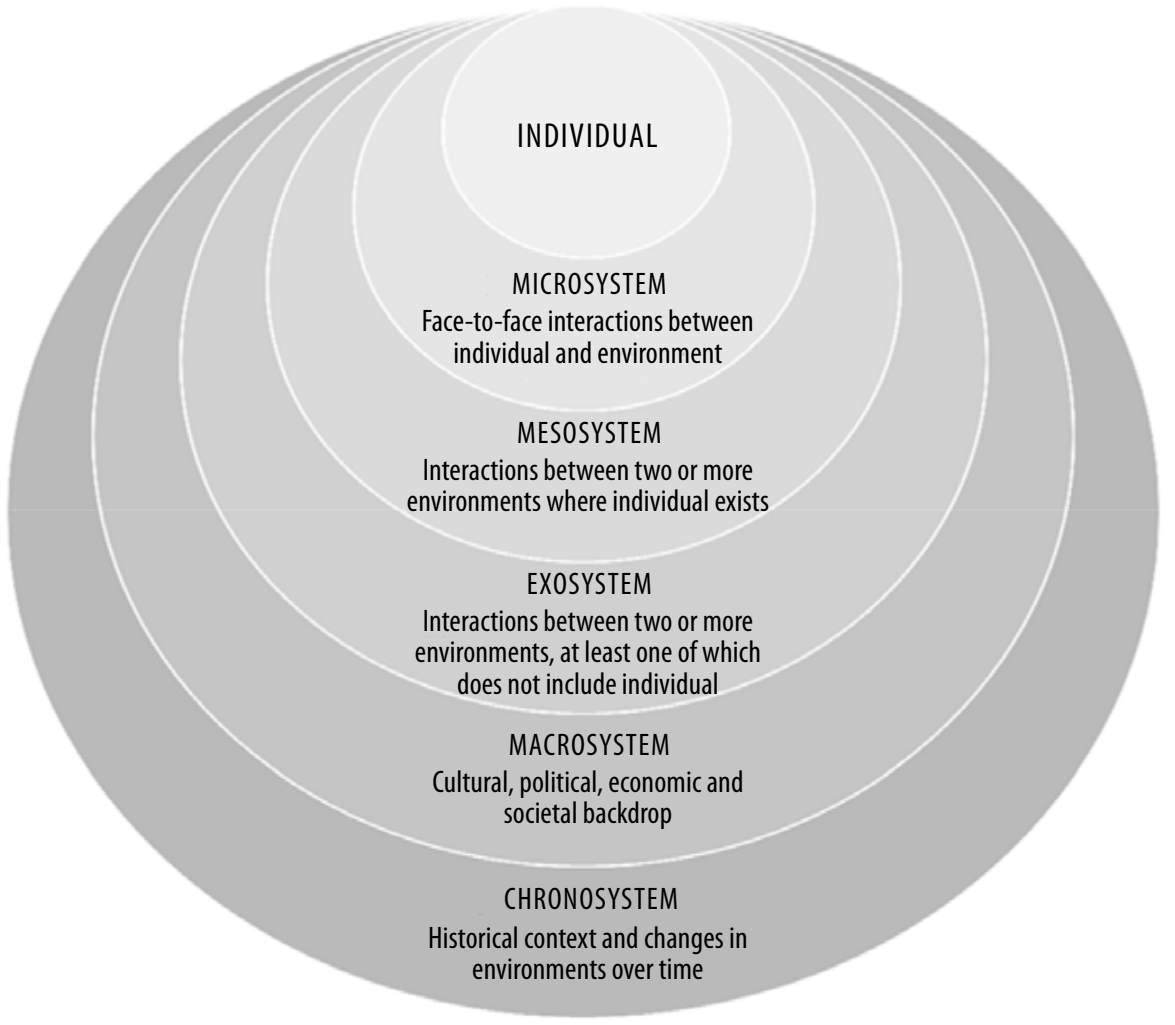

FIGURE 5.2 The bioecological model (Bronfenbrenner 1994)

The Multifactorial Model of Sobsey and Calder (1999) gives an explanation of violence against persons with disabilities. Based on the bioecological model, it combines various factors relevant to the increased risk that people with disabilities experience in terms of violence. The Multifactorial Model has eight components (Sobsey \& Calder 1999:10):

1. the potential victim

2. the potential offender

3. offender inhibition and disinhibition

4. potential victim - potential offender interactions

5. the relationship determining interactions

6. the social control agents

7. the environment of interactions

8. the culture in society influential to interactions

Interactions of a violent or intimidating nature between an offender and a person with a disability are considered to be victimisation (Sobsey \& Calder 1999:11). Anyone can be an offender. Of interest is the interaction between cultural stereotyping of disability and the offender's cognitive distortions. 


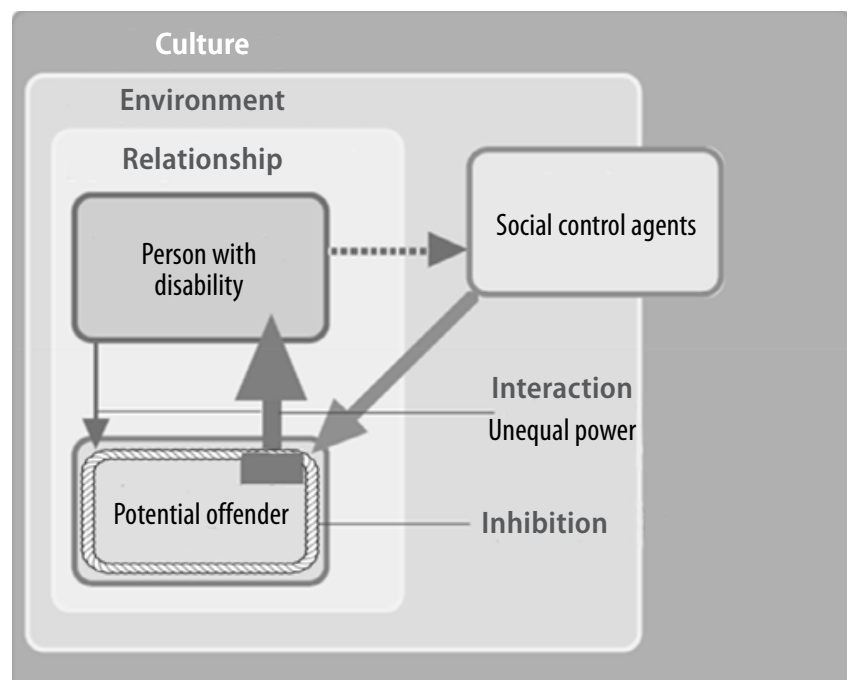

FIGURE 5.3 The Multifactorial Model of victimisation (Sobsey \& Calder 1999)

The diagram is clarified as follows (Sobsey \& Calder 1999:10-11):

Arrows indicate power. The size and direction of each arrow indicates relative strength and path of influence. The large arrow from the potential offender to the person with a disability narrows as it passes through the line designated as inhibition to signify the attenuation of force that may occur due to learned inhibition. The dashed arrow between the person with a disability and the social control agents symbolizes the fact that people with disabilities, like other crime victims, may not always be able to recruit assistance. The Social Control Agents shown here are partially within the environment shared by the potential offender and the person with a disability; actual agents of social control may or may not share the same environment. While arrows are not shown from the Social Control Agents to the person with a disability or from the Potential Offender to the Social Control Agents, power can follow those paths in some situations.

\section{FREEDOM FROM VIOLENCE, ABUSE AND EXPLOITATION}

According to Article 16 of the CRPD (UN 2007), appropriate measures must be taken in prevention of all forms of violence, abuse, and exploitation of persons with disabilities. Age-, gender- and disability-appropriate assistance and support should be provided to them, their families, and/or caregivers in its prevention, identification, report, investigation, and where applicable, prosecution. 
AAC ${ }^{1}$-supported testimony leads to conviction of sexual offender:

On 8 July 2020 justice was finally served in the Upington magistrate's court for a young adolescent after 8 years of struggle. The young girl who has cerebral palsy, a severe speech impairment and is unable to read and write fluently was sexually abused as a 7-year-old. The Centre for AAC was approached in 2017, and collaborated with the social worker, advocate and legal team from the National Prosecuting Authority (NPA), and the speech therapists from the local hospital over the course of the last three years. The collaboration included an assessment of the young girl, and the procurement and customization of a graphic symbolbased AAC device with Afrikaans synthetic voice output that was suited to her needs.

In addition, Prof Juan Bornman trained the legal team on court adaptations for persons using AAC, and Prof Kerstin Tönsing acted as expert witness, arguing for the AAC system to be allowed as a legitimate and independent communication method to deliver a testimony. The young girl received training from the locally based speech therapists in the use of the system, and was able to testify in court using the system in February this year. Her testimony contributed to the conviction of the accused on 8 July. This case is the first during which an AAC system of this nature was allowed to be used to give testimony in the sexual offences court. The case is hoped to set a legal precedent that will underline the role of AAC in the court to facilitate access to justice to persons with severe communication disabilities who are typically regarded as silent and helpless victims.

(Tönsing 2020)

\section{CONCLUSION}

The intersection between disability and violence is disturbing. The phenomena of violence and disability are multifaceted. However, the social model of disability helps us to see the individual with disability as a victim of social injustice. The well-being of persons with disabilities is in the hands of us, society. Like disability, violence is a societal problem. Society at large is responsible for and accountable to eliminate barriers to safety. "There should be introspection about the acknowledgement of one's community and the acknowledgement of one's own discriminatory attitude towards, and presuppositions about, people with disabilities" (Van Niekerk 2019:200-201).

According to Article 16 of the CRPD (UN 2007), appropriate measures must be taken in prevention of all forms of violence, abuse, and exploitation of persons with disabilities. Age-, gender- and disability-appropriate assistance and support should be provided to them, their families and/or caregivers in its prevention, identification, report, investigation and where applicable, prosecution.

$1 \quad$ Alternative and Augmentative Communication. 


\section{REFERENCES}

Anderson, P. \& Kitchin, R. 2000. Disability, space and sexuality: access to family planning services. Social Science $\mathcal{E}$ Medicine, 51:1163-1173. https://doi. org/10.1016/S0277-9536(00)00019-8

Bornman, J. 2014. Accessing Justice via Key Role Players: A View from South Africa. In: D.N. Bryen \& J. Bornman (eds.). Stop Violence Against Persons With Disabilities: An International Resource. PULP: Pretoria. pp. 41-82.

Bronfenbrenner, U. 1994. Ecological models of human development. In: International Encyclopaedia of Education. 2nd Edition. Elsevier: Oxford. pp. 37-43.

Businesstech. 2020. Cape Town now ranks as the 8th most violent city in the world. [Online]. https://bit.ly/3by74zg [Accessed 3 March 2021].

Capri, C., Watermeyer, B., Mckenzie, J. \& Coetzee, O. 2018. Intellectual disability in the Esidimeni tragedy: Silent deaths. South African Medical Journal, 108(3):153-154. https://doi.org/10.7196/SAMJ.2018.v10 8i3.13029

Centre for Applied Legal Studies (CALS). n.d. A Summary of the Criminal Law Sexual Offences Amendment Act 32 of 2007. [Online]. https://bit.ly/3CzNzSA [Accessed 5 March 2021].

Clements, J., Clare, I. \& Ezelle, L.A. 1995. Real Men, Real Women, Real Lives? Gender issues in learning disabilities and challenging behaviour. Disability E Society, 10(4):425-436. https://doi. org/10.1080/09687599550023435

Franklin, A., Lund, P., Bradbury-Jones, C. \& Taylor, J. 2018. Children with albinism in African regions: their rights to 'being' and 'doing'. BMC International Health and Human Rights, 18(2). https://doi. org/10.1186/s12914-018-0144-8

Higgins, M. \& Swain, J. 2010. Disability and Child Sexual Abuse. Lessons from Survivors' Narratives for Effective Protection, Prevention and Treatment. Philadelphia: London.

Humphrey, M. 2016. The intersectionality of poverty, disability, and gender as a framework to understand violence against women with disabilities: A case study of South Africa. International Development,
Community and Environment (IDCE), 36. Master of Arts in International Development and Social Change (IDSC) Research Paper. [Online]. https://bit.ly/ 3GJLFRN [Accessed 7 March 2021].

Iglesias, M., Gil, G., Joneken, A., Mickler, B. \& Knudsen, J.S. 1998. Violence and Disabled Women. Independent Living Institute. [Online]. https://bit.ly/3nR4VUQ [Accessed 8 March 2021].

Kabue, S. 2013. Exclusion through Perceptions and Attitudes towards Disability. EDAN Ecumenical Disability Advocates Network Quarterly Newsletter, April-June, pp. 2-3. [Online]. https://bit.ly/3w3t5zn [Accessed 8 March 2021].

Krug, E.G., Mercy, J.A., Dahlberg, L.L. \& Zwi, A.B. (eds.). 2002. World report on violence and health. World Health Organization: Geneva. https://doi.org/ 10.1016/S0140-6736(02)11133-0

Naidu, E., Haffejee, S., Vetten, L. \& Hargreaves, S. 2005. On the Margins: Violence Against Women With Disabilities. Center for the Study of Violence and Reconciliation. [Online]. https://bit.ly/ 31nmTa3 [Accessed 10 March 2021].

Neille, J. \& Penn, C. 2015. The Interface Between Violence, Disability, and Poverty: Stories From a Developing Country. Journal of Interpersonal Violence, pp. 1-25. https:// doi.org/10.1177/0886260515596332

Powers, L.E. \& Oschwald, M. 2004. Violence and Abuse against People with Disabilities: Experiences, Barriers and Prevention Strategies. Oregon Health \& Science University: Oregon.

Sobsey, D. \& Calder, P. 1999. Violence against persons with disabilities: A conceptual analysis. [Online]. https://bit.ly/3EEJ4qH [Accessed 21 February 2021].

Statistics South Africa. 2014. Census 2011: Profile of persons with disabilities in South Africa. [Online]. https://bit.ly/3nMq4j8 [Accessed 25 February 2021].

Tönsing, K. 2020. AAC-supported testimony leads to conviction of sexual offender. Centre for Augmentative and Alternative Communication. University of Pretoria: Pretoria. [Online]. https://bit.ly/2ZHg1TW [Accessed 15 March 2021]. 
UNICEF. 2014. Conceptualizing Inclusive Education and Contextualizing it within the UNICEF Mission. Webinar 1 Companion Technical Booklet. UNICEF: New York.

United Nations (UN). 2007. Convention on the Rights of Persons with Disabilities and Optional Protocol. UN: New York.

Van der Heijden, I., Abrahams, N. \& Harries, J. 2016. Additional Layers of Violence: The Intersections of Gender and Disability in the Violence Experiences of Women With Physical Disabilities in South Africa. Journal of Interpersonal Violence, pp. 1-22. https://doi.org/10.1177/0886260516645818

Van Niekerk, P.I. 2019. Missional Spirituality and the Embodiment of Imperfection. $\mathrm{PhD}$ thesis. University of Pretoria: Pretoria.
Van Niekerk, P.I. 2018. Health and brokenness: Aren't we all clay jars? An ethical reflection on health and brokenness. In: C. Jones (ed.). Justice-based ethics: Challenging South African perspectives. AOSIS: Cape Town. pp. 165-192. https://doi.org/10.4102/ aosis.2018.BK77.07

Vorster, R.W. \& Magnes, T-J. 2018. Child victims of violence: The stories behind SA's child abuse statistics. [Online]. https://bit. ly/3EzDoOv [Accessed 18 March 2021].

WHO (World Health Organization). 2001. International Classification of Functioning, Disability and Health. WHO: Geneva.

WHO (World Health Organization). n.d. Sexual exploitation and abuse, Prevent and Protect: What you need to know and do. [Online]. https://bit.ly/3CFLDIk 